\title{
Competition for light causes plant biodiversity loss after eutrophication
}

Hautier, Y ; Niklaus, P A ; Hector, A

\begin{abstract}
Human activities have increased the availability of nutrients in terrestrial and aquatic ecosystems. In grasslands, this eutrophication causes loss of plant species diversity, but the mechanism of this loss has been difficult to determine. Using experimental grassland plant communities, we found that addition of light to the grassland understory prevented the loss of biodiversity caused by eutrophication. There was no detectable role for competition for soil resources in diversity loss. Thus, competition for light is a major mechanism of plant diversity loss after eutrophication and explains the particular threat of eutrophication to plant diversity. Our conclusions have implications for grassland management and conservation policy and underscore the need to control nutrient enrichment if plant diversity is to be preserved.
\end{abstract}

DOI: https://doi.org/10.1126/science.1169640

Posted at the Zurich Open Repository and Archive, University of Zurich ZORA URL: https://doi.org/10.5167/uzh-18666

Journal Article

Accepted Version

Originally published at:

Hautier, Y; Niklaus, P A; Hector, A (2009). Competition for light causes plant biodiversity loss after eutrophication. Science, 324(5927):636-638.

DOI: https://doi.org/10.1126/science.1169640 


\section{Competition for Light Causes Plant Biodiversity Loss Following Eutrophication}

\author{
Yann Hautier, ${ }^{1 *}$ Pascal A. Niklaus,,${ }^{1,2}$ Andy Hector ${ }^{1}$
}

Human activities have increased the availability of nutrients in terrestrial and aquatic ecosystems. In grasslands this eutrophication causes loss of plant species diversity, but a mechanistic understanding of this loss has been lacking. Here, using experimental grassland plant communities, we found that addition of light to the grassland understory prevented the loss of biodiversity caused by eutrophication. There was no detectable role for competition for soil resources on diversity loss. Thus, competition for light is a major mechanism of plant diversity loss following eutrophication and explains the particular threat of eutrophication to plant diversity. Our conclusions have implications for grassland management and conservation policy and emphasize the need to control nutrient enrichment if plant diversity is to be preserved.

$\mathrm{F}$ ertilization experiments (1-4) and studies of nutrient deposition in terrestrial ecosystems (5) show that increases in the availability of nitrogen $(5,6)$ phosphorus (7) and other nutrients, both alone and in combination $(1,4)$, usually increase primary productivity and decrease plant diversity. Given that anthropogenic activity has doubled global phosphorus liberation and plant available nitrogen during the last half century $(8,9)$, and that nutrient inputs are predicted to be one of the three major drivers of biodiversity loss this century (10), understanding the mechanisms responsible for diversity loss following eutrophication is an important basis for the development of effective conservation policies (11)

Most of the hypotheses proposed to explain the reduction in plant diversity following eutrophication focus on changes in competition (12-15). Fertilization may increase the strength of competition generally, that is both above and below ground (15), or it could increase the strength of aboveground competition for light only: an asymmetric process due to the directional supply of this resource $(13,14)$. The hypothesis of increased competition for light (14) predicts that as productivity increases, availability of light to plants in the understory is reduced, leading to their exclusion by fastergrowing or taller species that pre-empt this directionally supplied resource $(16,17)$. Surprisingly, 35 years after these alternative hypotheses were suggested, there is no consensus on the role of competition as a mechanism of plant diversity loss following eutrophication $(18,19)$.

To test if diversity loss following eutrophication is due to increased competition for

${ }^{1}$ Institute of Environmental Sciences, University of Zurich, Winterthurerstrasse 190, $\mathrm{CH}-8057$ Zurich, Switzerland. ' Institute of Plant Sciences, ETH Zurich, Universitätstrasse 2, CH-8092 Zurich, Switzerland.

*To whom correspondence should be addressed. E-mail: yhautier@uwinst.uzh.ch light, we added light to the understory of fertilized grassland communities; a manipulation inspired by competition experiments with algae $(20,21)$. A key advance of our approach relative to earlier work (22) is that it restores light

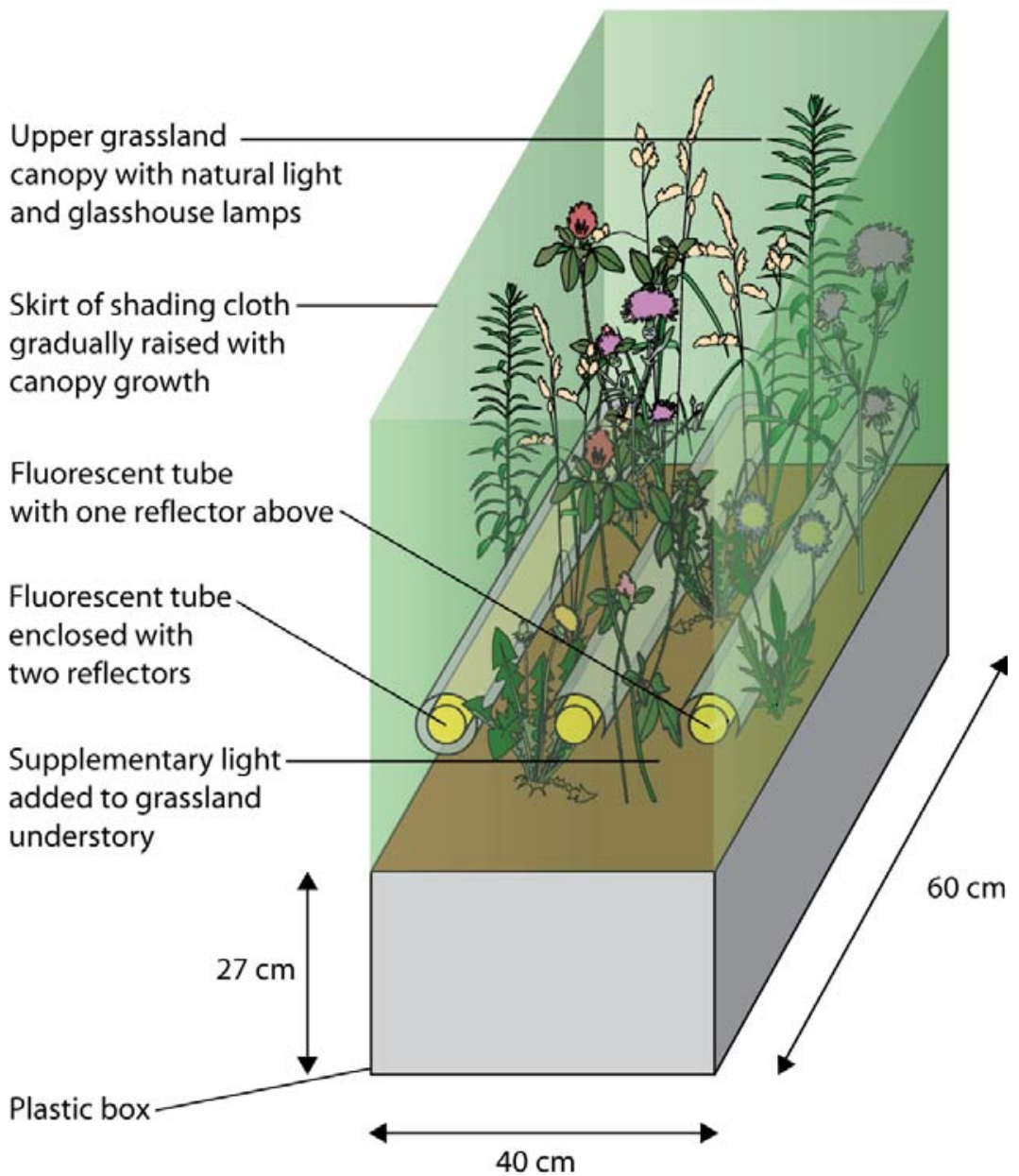

Fig. 1. Schematic representation of the experimental understory light addition. To save space, two open lights and one closed light are shown in the same experimental unit. The four treatment combinations were "control" (unfertilized, closed lights), "fertilization" (fertilized, closed lights), "light" (unfertilized, open lights), and "fertilization + light" (fertilized, open lights). For generality these four treatments were applied to four different plant communities with each combination replicated twice $(n=4 \times 4 \times 2=32)$. 
understory while holding other conditions cally, supplementing understory light in the (such as temperature) constant. Aboveground fertilization treatment to levels similar to the biomass was harvested twice a year during control plots prevented the loss of species and 2006 and 2007 to coincide with the cutting maintained comparable levels of diversity (Fig. regimes typical of European meadows, and 2C). This result was general across the four other key variables including belowground different plant communities used in the exbiomass production, canopy height, availability of light in the understory, soil $\mathrm{pH}$ and plant diversity were regularly monitored (24).

After two years of treatment, fertilization had increased net aboveground biomass production and decreased diversity (25). During the second year, fertilization significantly increased production from an average of $356 \pm$ $39 \mathrm{~g} \mathrm{~m}^{-2}$ (mean \pm s.e.m.) per harvest in the control communities to $450 \pm 39 \mathrm{~g} \mathrm{~m}^{-2}$ in the fertilized treatment (Fig. 2A; Table S1). Light in the understory of the fertilized plots $(5 \pm$ $4 \%$ ) was significantly lower compared with the controls (13 $\pm 4 \%$ ); (Fig.2B). Notably, when increased production was accompanied by decreased light in the understory, fertilization significantly reduced species richness (Fig. 2C): on average 2.6 species were lost in the fertilization treatment compared with the control, around $1 / 4$ of the original species richness. This loss of diversity following eutrophication is consistent with longer-term field studies ( 1 , $5)$.

When applied together with fertilization, the additional understory light compensated for the increased shading caused by the greater aboveground biomass production and generated levels of understory light $(12 \pm 4 \%)$ that were indistinguishable from those in the control plots $(13 \pm 4 \%)$; (Fig. $2 \mathrm{~B}$; Table S1). Criti-

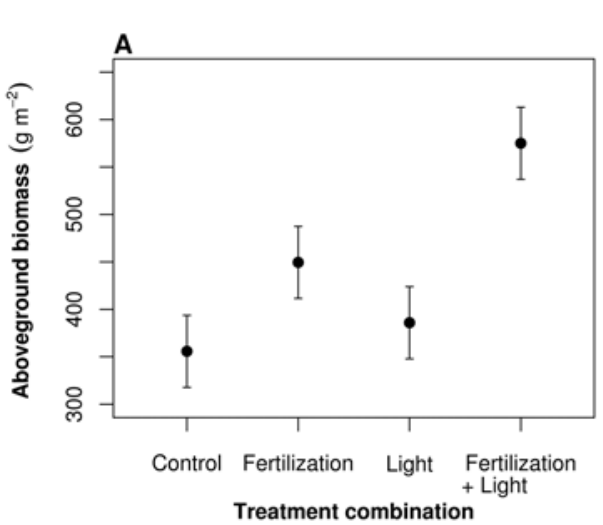

Fig. 2. Effects of fertilization and supplementary understory light on grassland diversity and functioning. (A). Average aboveground plant biomass per harvest in 2007. Addition of fertilizer and fertilizer-plus-light significantly increased above-ground biomass. (B). Light in 2007 measured as PAR (photosynthetically active radiation). Increased aboveground biomass significantly reduced light availability in the understory unless compensated by experimental illumination to levels comparable to control plots. (C). Species richness between 2006 and 2007. Fertilization significantly reduced species richness unless prevented by the addition of supplementary light to the understory. Points denote treatment means and the intervals show least significant differences (treatments with non-overlapping intervals are significantly different at $\mathrm{P}=$ 0.05).
Our understory light addition treatment also had consequences for ecosystem functioning. Net aboveground biomass production in the controls was limited by nutrients (although we cannot exclude light limitation of the taller species too) since it was increased by fertilization (Fig. 2A, Table S1). Without fertilization the productivity of plants in the understory was not light limited since when applied to unfertilized communities supplementary light had no effect (Fig. 2A). However, the productivity of plants in the understory of the fertilization treatment was light limited since in fertilized communities the additional light increased average net aboveground production per harvest to $575 \pm 39 \mathrm{~g} \mathrm{~m}^{-2}$ (Fig. $2 \mathrm{~A}$ ). These responses suggest co-limitation of productivity by light and nutrients where the taller species are nutrient limited while understory species in the fertilization treatment are light limited. More generally, our results suggest that productivity of the upper canopy and understory can be limited by different factors due to the directional supply of light.

Species loss could be due to increased competition both above- and belowground (15). To address this, in the second year of the glasshouse experiment we added seedlings of two species not originally present to the 32 experimental communities to measure the strength of belowground competition. Transplanted seedlings planted in plastic tubes to reduce belowground competition were compared with seedlings exposed to full root competition. The results were also consistent with competition for light as the main mechanism of diversity loss: when grown without root exclusion tubes (that is, with belowground competition), seedling mortality (as a proportion) strongly increased with nutrient addition from 0.29 to 0.87 , but was comparable to control plots when fertilization occurred together with understory lighting (Fig. 4; Table S3A). The results provided no support for a role of belowground competition in the loss of biodiversity (Table S4): removing belowground competition from fertilized plots had no detectable

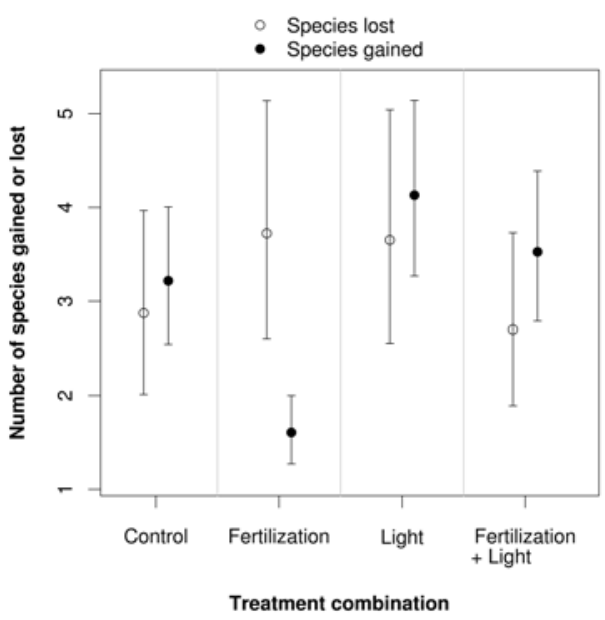

Fig. 3. Species turnover. Decreased diversity in fertilized plots was mainly caused by reduced numbers of species gained. Results are shown as in Fig. 2. 
impact on seedling mortality (Table S3B) or Critically, supplementing levels of understory seedling biomass (change in biomass $=0.3 \mathrm{~g}$, light in fertilized communities reduced compe$95 \% \mathrm{CI}=-1.0-1.4)$

While other processes can also contribute to diversity loss there was no evidence that they were important in our study. Fertilization can reduce grassland diversity through acidification (2) or through the accumulation of plant litter $(26,27,29,30)$. However, we found no detectable differences in $\mathrm{pH}$ following fertilization (Fig. S1; Table S5). There was also little build-up of litter during our experiment suggesting that the negative effects of increased aboveground productivity might have strengthened in the longer term if litter accumulation had occurred.

Together, our results are consistent with increased competition for light as a major mechanism of diversity loss following eutrophication of grassland communities. Fertilization increased productivity and canopy height, and reduced light in the understory. This led to a reduction in diversity, particularly of lowstatured perennial grasses and forbs, mainly through reduced recruitment. While other mechanisms also cause loss of plant diversity they played no detectable role in our case.

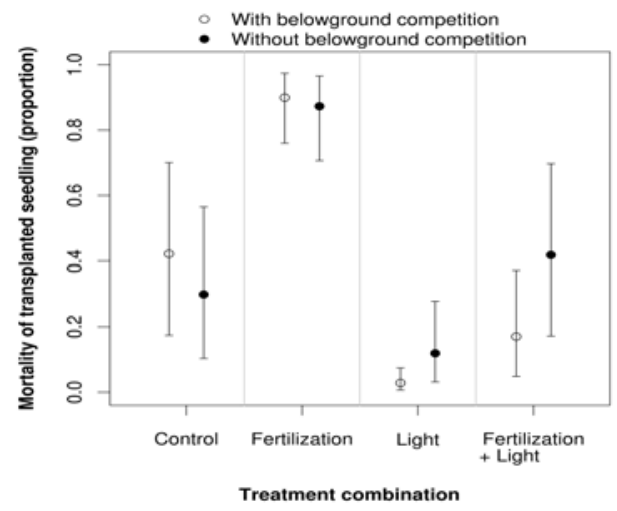

Fig. 4. Seedling mortality. Fertilization significantly increased seedling mortality. Removing belowground competition had little impact on seedling mortality, which suggests that competition for soil resources plays no detectable role in diversity loss. Results are shown as in Fig. 2. tition for light, sustained seedling establishment and maintained plant diversity despite the additional nutrient inputs. Some earlier studies (31) have demonstrated the importance of competition for light indirectly by tying back the vegetation. Our results advance a long running debate in community ecology by providing a direct experimental demonstration of the importance of asymmetric competition for light as a mechanism of plant diversity loss. More generally, our work explains and emphasizes the need to develop conservation policies and management procedures that prevent eutrophication if biodiversity is to be conserved (32).

\section{References and Notes}

1. W. S. Harpole, D. Tilman, Nature 446, 791 (2007).

2. J. Silvertown et al., Journal of Ecology 94 , 801 (2006).

3. L. Gough, C. W. Osenberg, K. L. Gross, S. L. Collins, Oikos 89, 428 (2000).

4. M. J. Crawley et al., American Naturalist 165, 179 (2005).

5. C. J. Stevens, N. B. Dise, J. O. Mountford, D. J. Gowing, Science 303, 1876 (2004).

6. C. M. Clark, D. Tilman, Nature 451, 712 (2008).

7. M. J. Wassen, H. O. Venterink, E. D. Lapshina, F. Tanneberger, Nature 437547 (2005).

8. P. M. Vitousek, H. A. Mooney, J. Lubchenco, J. M. Melillo, Science 277, 494 (1997)

9. D. Tilman et al., Science 292, 281 (2001).

11. D. Tilman, K. G. Cassman, P. A. Matson, R. Naylor, S. Polasky, Nature 418, 671 (2002)

12. J. P. Grime, Plant Strategies, Vegetation Processes, and Ecosystem Properties (John Wiley and sons, Chichester, ed. 2, 2002).

13. D. Tilman, Resource Competition and Community Structure (Princeton Univ. Press, Princeton, 1982).
10. O. E. Sala et al., Science 287, 1770 (2000).

14. E. I. Newman, Nature 244, 310 (1973).
15. J. P. Grime, Nature 242, 344 (1973).

16. K. N. Suding et al., Proceedings Of The National Academy Of Sciences Of The United States Of America 102, 4387 (2005).

17. E. Vojtech, L. A. Turnbull, A. Hector, PLOS ONE 2, e499 (2007).

18. C. M. Clark et al., Ecology Letters 10, 596 (2007).

19. T. K. Rajaniemi, Oikos 101, 449 (2003).

20. J. Huisman, R. R. Jonker, C. Zonneveld, F. J. Weissing, Ecology 80, 211 (1999).

21. J. Passarge, S. Hol, M. Escher, J. Huisman, Ecol. Monogr. 76, 57 (2006).

22. L. Eek, K. Zobel, Ecography 24, 157 (2001).

23. L. Wacker, O. Baudois, S. EichenbergerGlinz, B. Schmid, Basic and Applied Ecology 9, 467 (2008).

24. Materials and methods are available as supporting material on Science Online.

25. B. L. Foster, K. L. Gross, Ecology 79, 2593 (1998).

26. D. Tilman, Ecology 74, 2179 (1993).

27. M. H. H. Stevens, D. E. Bunker, S. A Schnitzer, W. P. Carson, Journal Of Ecology 92, 339 (2004).

28. F. Berendse, Trends in Ecology \& Evolution 14, 4 (1999)

29. E. G. Lamb, Ecology 89, 216 (2008)

30. N. C. Emery, P. J. Ewanchuk, M. D. Bertness, Ecology 82, 2471 (2001).

31. We thank E.-D. Schulze and C. Körner for discussion of light manipulation, B. Schmid and $L$. Turnbull for comments on the manuscript and L. Wacker, E. Vojtech, G. Feichtinger and T. Zwimpfer for helpful suggestions and field work assistance. Y.H. is funded by Swiss National Foundation grant 3100A0-107572 to A.H. The project was conceived by A.H., designed by A.H., P.A.N. and Y.H., conducted by Y.H., analysed by Y.H. and A.H. and written up by Y.H. and A.H. with inputfrom P.A.N.

\section{Supporting Online Material}

www.sciencemag.org/cgi/content/full/324/5927/6 36/DC1

Materials and Methods

SOM text

Figs S1 to S3

Tables S1 to S7

References 


\section{Supporting Material}

\section{Materials and Methods}

Experimental design. We used pre-established 4 year old communities from an existing experiment (S1). For generality, the communities consisted of four different 6species mixtures containing grasses, legumes and forbs (Table S6). In September 2005, 32 soilplant communities, each $60 \times 40 \times$ $27 \mathrm{~cm}$ were extracted from this field and transferred to an experimental glasshouse. Weeding of the unsown species ensured that the maximum richness at the time of extraction was 6 species and the realized richness of the 4 communities ranged between $3.1 \pm 0.83$ and $5.9 \pm 0.35$ species (mean \pm s.d.). Plant communities with intact soil blocks were placed in plastic boxes with perforated bottoms. Communities were insulated with expanded polystyrene and installed in the garden of the University of Zurich for the winters between 2005/2006 and between 2006/2007. In April 2006, communities were transferred to a shaded compartment of an experimental glasshouse of the University of Zurich $\left(43^{\circ} 23^{\prime} \mathrm{N}\right.$, $8^{\circ} 33^{\prime} \mathrm{E}$, altitude $549 \mathrm{~m}$ a.s.1.). Communities were watered daily throughout the growing season to keep them moist and were not weeded. After weeding stopped, recruitment of species from the seed bank increased diversity to an average of 7.7 (s.d. $=2.0$ ) species per $0.24 \mathrm{~m}^{2}$ in 2006 before treatment effects emerged in 2007 and reduced the richness of fertilized communities. Each of the 32 communities was harvested twice a year for two years to coincide with the cutting typical of European meadows. Beginning in April 2006, we applied a fully-factorial combination of nutrient addition and supplementary understory illumination (both either applied or not applied) for two years. The four treatment combinations applied to four different species mixtures, each replicated twice, produced 32 experimental units in total.

Fertilization. In order to reproduce the loss of plant species diversity that usually follows fertilization in the field, we applied a mixture of nutrient commonly used in agriculture in Switzerland (following http://www.landor.ch/fra/3960. aspx? artNr=16612). Fertilizer was supplied in dry form in 4 applications over the growing season at rates ( $\mathrm{g}$ per $\mathrm{m}^{2}$ per year) of $15 \mathrm{~N}$, $3.5 \mathrm{P}$ and a cation mix of $6 \mathrm{~K}, 1.5$ $\mathrm{Mg}, 2.25 \mathrm{Na}$ and $2.25 \mathrm{~S}$ (Nitrolplus, Landi, Switzerland) in 2006. Because this only marginally increased biomass, in 2007 fertilization was increased to $20 \mathrm{~N}, 5 \mathrm{P}$ and a cation mix of $8 \mathrm{~K}, 2 \mathrm{Mg}, 3 \mathrm{Na}$ and $3 \mathrm{~S}$. $\mathrm{N}$ was supplied as $\mathrm{NH}_{4}$ and $\mathrm{NO}_{3}$ in equal proportions, $\mathrm{P}$ as $\mathrm{P}_{2} \mathrm{O}_{5}, \mathrm{~K}$ as $\mathrm{KCl}$ and $\mathrm{Mg}$ and $\mathrm{S}$ as $\mathrm{MgCO}_{3}$ and $\mathrm{MgSO}_{4}$.

Light addition to the understory. Understory illumination was applied continuously with three parallel fluorescent tubes and reflectors placed in parallel and horizontally above each community at an average height of $15 \mathrm{~cm}$ over the soil. The fluorescent tubes $(24 \mathrm{~W}$, $6500 \mathrm{~K}, \mathrm{~T} 5 \mathrm{HO}$, OSRAM, Winterthur, Switzerland) were $55 \mathrm{~cm}$ long and $1.6 \mathrm{~cm}$ diameter and produced a light spectrum close to that of the main glasshouse lamps which were specialized for plant growth (400 W, 6500 K, Metal Halide Retrofit from Mercury). We surrounded the supplementary lighting units with a metal grid (1 cm mesh) and a plastic wrap to prevent contact of plants with the fluorescent tubes. The increase in temperature (0.9 ${ }^{\circ} \mathrm{C}$, s.d. $\left.=0.6\right)$ due to the additional light was relatively small and there was no significant difference in the temperature around the fluorescent tubes between treatments with and without understory light (Fig. S2; Table S7, 95\% CI $=-0.3-0.4)$, that is between the open and closed fluorescent tubes; thus controlling for any potential effects of increased temperature by equalizing it across treatments. To protect the vegetation, all reflectors were covered with foam $(0.5 \mathrm{~cm}$ thick). Moreover, eight rotating fans were placed regularly in the glasshouse to disperse the heat throughout the climate-controlled compartment. Both the glasshouse light and the supplementary understory light were on a 14 hour regime. To mimic surrounding vegetation, skirts of $63 \%$ shading clothes were placed around all communities and raised to keep pace with the canopy growth (2007 only).

Measurements. We measured aboveground plant biomass production and species composition at peak biomass in early June and 
September 2006 and 2007 by clipping the entire communities at a height of $2 \mathrm{~cm}$, sorting to species, drying to constant mass in ovens and weighing. The annual aboveground net primary productivity of plant communities within our experimental glasshouse ranged from 305 to $1501 \mathrm{~g} \mathrm{~m}-2$, which is in the range of those observed for European grasslands ( 150 to $>1500 \mathrm{~g} \mathrm{~m}-$ 2) (S2). A species was considered lost from a plot if it was present in a harvest in 2006 but absent in the same harvest in 2007 and gained if it was absent in 2006 but present in 2007. Species were classified into 6 groups as being either annual or perennial grasses, legumes or forbs, and into 4 groups according to whether their canopies were basal or leafy and taller or shorter than $30 \mathrm{~cm}$. Species gains and losses were calculated per group by comparing the composition of each plot in $2006 v s$ 2007. The percentage of transmitted photosynthetically active radiation (PAR) reaching the soil surface was measured before cutting using a ceptometer (Sunscan, Delta-T Devices, Cambridge, UK) taking 3 replicate readings across each plot. In 2007, we used root-ingrowth cores (PVC drilled tube of $5 \mathrm{~cm}$ diameter and $25 \mathrm{~cm}$ deep (S3) buried at an angle of $45^{\circ}$ in the soil of each community to estimate belowground root productivity. Ingrowth cores were filled with root-free soil sieved (1 $\mathrm{cm}$ mesh) during the collection of communities and stored at $4^{\circ} \mathrm{C}$. At both peak growth and peak biomass, cores were extracted and roots were separated (sieve, $1 \mathrm{~mm}$ mesh), washed to remove soil residue, dried and weighed. In 2007, soil samples were collected at both peak growth and peak biomass, sieved (1 mm mesh) and analyzed for $\mathrm{pH}$ (Labor für Bodenund Umweltanalytik, Thun, Switzerland).

Transplanted seedlings. Twoweek old seedlings of Rumex acetosella and Plantago media were transplanted at the beginning of April and middle of June 2007 (following harvest) and grown with or without belowground interspecific competition. Planting holes were filled with root-free soil. Seedling mortality was recorded before communities clipping.

Analysis. We used generalized linear mixed-effects models (S4) since our design includes fixed and random effects and our responses include variables with normal and non-normal error distributions. Generalized linear mixed-effects models (GLMMs) (S5-S8) are generalized linear model that include random effects. The GLMM analyses were implemented, using restricted maximum likelihood, with the lmer function from the lme4 library (S5) for R 2.8.0 (S8). In the text we present estimates of the means from the GLMMs with their standard errors and in the graphs estimates are given with interval bars to indicate least significant differences (1.s.d.) at $\mathrm{P}=0.05$ (treatments with non-overlapping intervals are significantly different). Data that were analysed using normal error distribution included productivity, light levels, changes in diversity, canopy height, rootshoot ratios and $\mathrm{pH}$. Data with nonnormal error distributions included seedling mortality, which was analysed with a binomial error distribution, and species turnover, which was analysed with a Poisson error distribution. For the analysis of the main fertilization and light addition factorial design, the fertilization and light treatments were treated as fixed effects, and species pools, plots (the 32 individual soil-plant communities) and harvests (two repeated measures per plot within a given year, with years analysed separately) were treated as random effects. In the analysis of the performance of the transplanted seedlings, the fertilization, light addition and root exclusion tube treatments were treated as fixed effects and species pools, plots, harvests and species identity of the transplanted seedlings were treated as random effects. Random effects for the interaction between species pools and the fertilization and light treatments were very small and non-significant and were excluded during the model building process.

\section{Supporting text}

First year result In the first year of our experiment nutrient addition increased above-ground production marginally from $427 \pm$ $162 \mathrm{~g} \mathrm{~m}^{-2}$ per harvest (mean \pm s.e.m.) for the control communities to $496 \pm 162 \mathrm{~g} \mathrm{~m}^{-2}$ for the fertilized treatment (Table S1). Levels of light in the understory of the fertilized plots $(12 \pm 8 \%)$ were similar 
to the control plots $(13 \pm 8 \%)$ with no significant difference between the two (Table S1). This was probably due to a lack of surrounding vegetation which allowed the vegetation to spread out and light to penetrate into the experimental communities from the side. Levels of diversity in the fertilized plots $(7.6 \pm 1.1)$ were also very similar to those in the control communities (7.1 \pm 1.1$)$ with no significant change despite the increased levels of productivity (Table S1), which we hypothesized was probably due to the failure of the fertilization treatment to reduce light availability in the understory during the first year.
Species traits and species loss The decline in species richness in the nutrient addition treatment was mainly due to reduced gains of perennial grass species $(95 \% \mathrm{CI}=$ $-1.2-0.05)$ and perennial forbs $(95 \% \mathrm{CI}=-2.3-0.09)$ that were both marginally significant. Gains and losses of annual grasses, annual forbs and annual and perennial legumes were independent of productivity. Plants with basal leaves and lower than $30 \mathrm{~cm}$ in height also had marginally significantly reduced gains in the fertilized treatment relative to the control $(95 \%$ $\mathrm{CI}=-0.1-1.2)$. Hence, most of the changes in species richness with nutrient addition were driven by lower colonization (including from seed bank) of low-growing species of perennial grasses and forbs, while exclusion of established species was not affected.

The role of belowground competition: root-shoot ratios The results provided no support for a role of belowground competition in the loss of biodiversity: removing belowground competition from fertilized plots had no impact on seedling mortality. Lack of effects of fertilization on community rootshoot ratio, which is presumably related to of the strength of belowground competition, supports this observation (Fig. S3).

\section{Supporting figures}

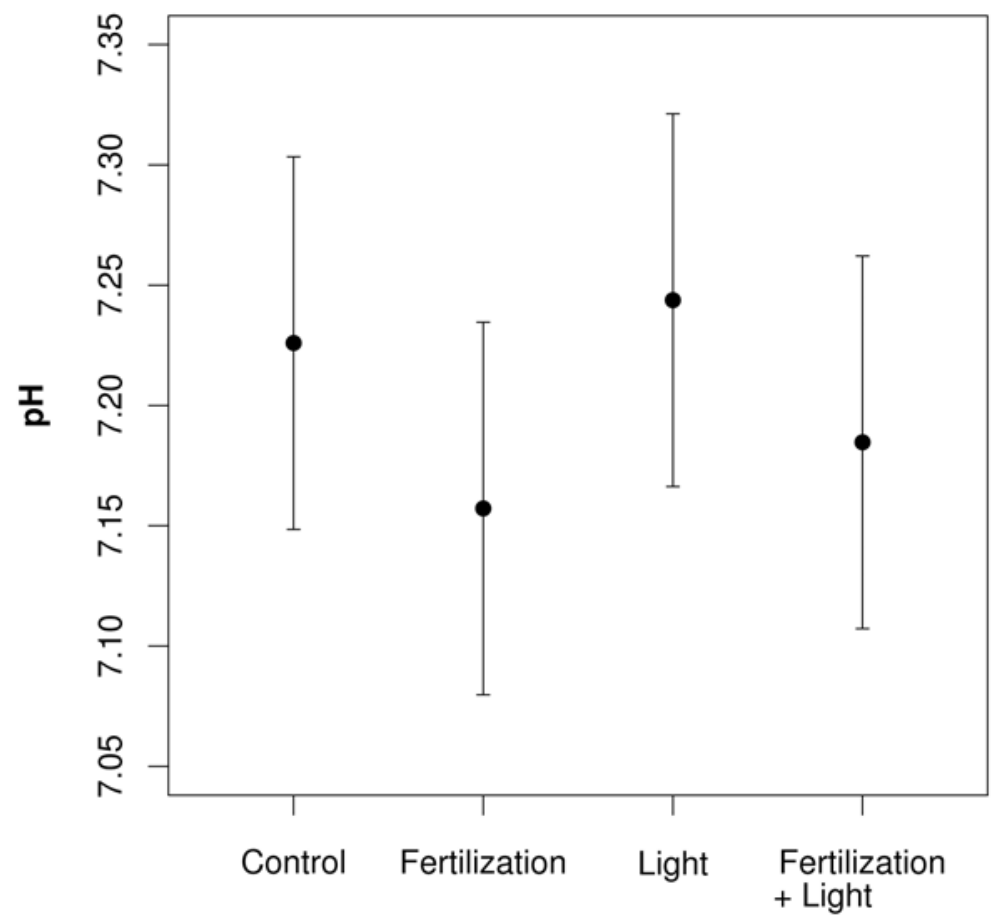

Figure S1. Effects of fertilization and supplementary understory light on $\mathrm{pH}$ in 2007. There was little variation in $\mathrm{pH}$ and no detectable differences following fertilization. Results are shown as means \pm l.s.d.

Treatment combination 

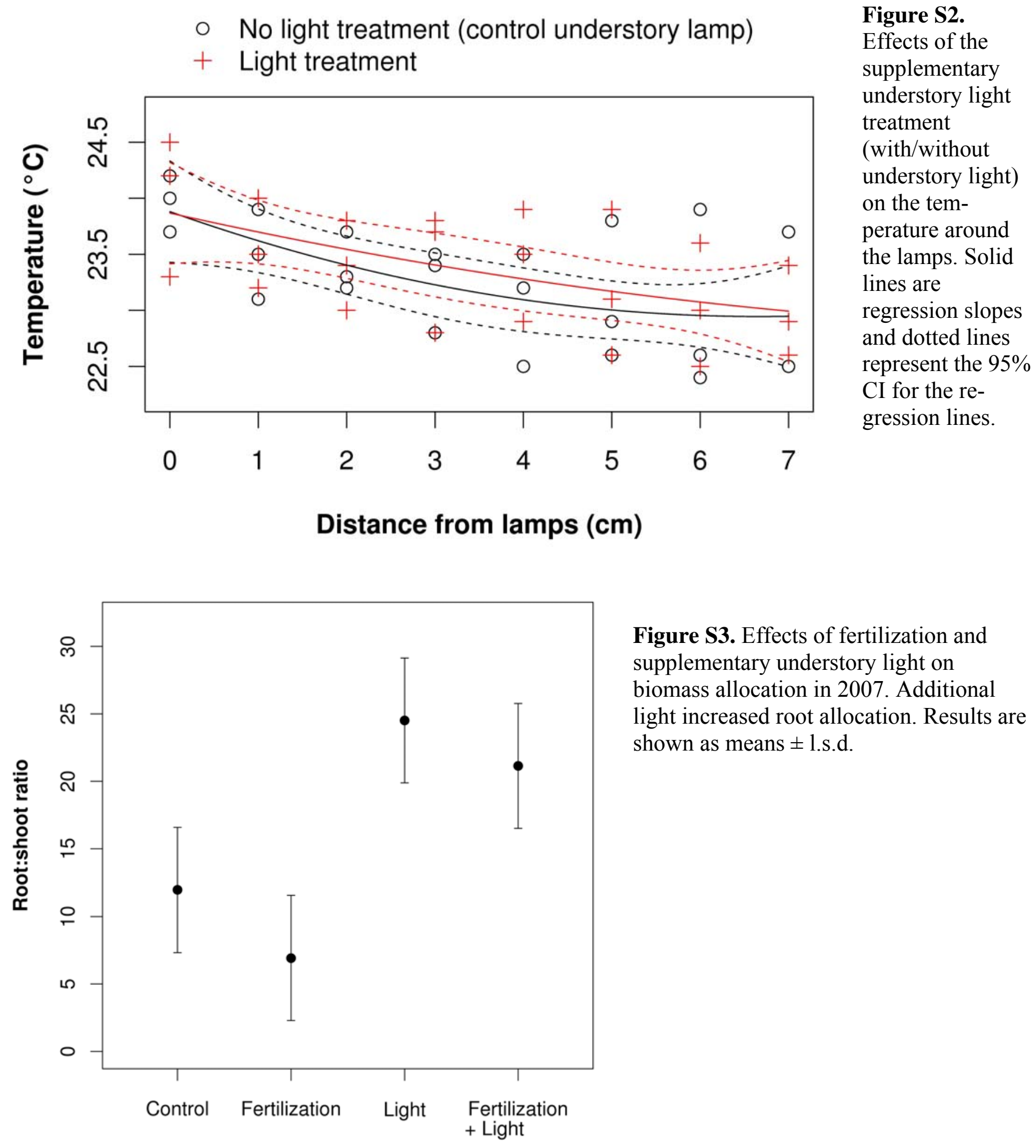

Figure S3. Effects of fertilization and supplementary understory light on biomass allocation in 2007. Additional light increased root allocation. Results are shown as means \pm l.s.d.

Treatment combination 


\section{Supporting tables}

Table S1. Effect (productivity, percentage of transmitted light at ground level (PAR) in 2006 and in 2007, species richness in 2006, and changes in species number between 2006 and 2007) of experimental fertilization and supplementary understory light. Results are shown as mean and 95\% CI.

\begin{tabular}{l|lll|lll|lll}
2006 & \multicolumn{3}{|l|}{ Productivity } & \multicolumn{3}{|l}{ PAR } & & \multicolumn{3}{l}{ Species richness in 2006} \\
\hline Source & Effect & $2.5 \%$ & $97.5 \%$ & Effect & $2.5 \%$ & $97.5 \%$ & Effect & $2.5 \%$ & $97.5 \%$ \\
\hline Control & 427 & & & 13 & & & 7.1 & & \\
Fertilization & 69 & -10 & 146 & -1 & -10 & 7 & 0.5 & -0.8 & 1.6 \\
Light & -21 & -96 & 60 & 2 & -6 & 10 & 1.1 & -0.1 & 2.4 \\
$\begin{array}{l}\text { Fertilization }+ \\
\text { Light }\end{array}$ & 77 & -4 & 153 & 2 & -6 & 10 & 1.0 & -0.2 & 2.3 \\
\hline
\end{tabular}

\begin{tabular}{l|lll|lll|lll}
2007 & \multicolumn{2}{|l|}{ Productivity } & & & & & \multicolumn{2}{l}{$\begin{array}{l}\text { Change in species richness } \\
\text { between 2006 and 2007 }\end{array}$} \\
\hline Source & Effect & $2.5 \%$ & $97.5 \%$ & Effect & $2.5 \%$ & $97.5 \%$ & Effect & $2.5 \%$ & $97.5 \%$ \\
\hline Control & 356 & & & 13 & & & 0.3 & & \\
Fertilization & 94 & 22 & 166 & -8 & -16 & -0.5 & -2.6 & -4.4 & -0.6 \\
Light & 30 & -43 & 103 & 8 & 0.5 & 16 & 0.1 & -1.78 & 2.0 \\
$\begin{array}{l}\text { Fertilization }+ \\
\text { Light }\end{array}$ & 219 & 147 & 291 & -1 & -9 & 6 & 0.5 & -1.4 & 2.4 \\
\hline
\end{tabular}

The effects are reported as the value for the control and the differences (in italics) between control and the other treatments. 
Table S2. Effect (species gained and lost between 2006 and 2007) of experimental fertilization and supplementary understory light. Results are shown as mean and $95 \%$ CI.

\begin{tabular}{l|lll|lll} 
& Gain & & & Loss & \\
\hline Source & Effect & $2.5 \%$ & $97.5 \%$ & Effect & $2.5 \%$ & $97.5 \%$ \\
\hline Control & 1.2 & & & 1.1 & & \\
Fertilization & -0.7 & -1.2 & -0.2 & 0.3 & -0.1 & 0.6 \\
Light & 0.3 & -0.1 & 0.6 & 0.2 & -0.1 & 0.6 \\
Fertilization + & 0.1 & -0.3 & 0.5 & -0.1 & -0.5 & 0.3 \\
Light & & & & & & \\
\hline
\end{tabular}

The effects are reported as the value for the control and the differences (in italics) between control and the other treatments. 
Table S3. Effect (mortality of transplanted seedling) A. Of experimental fertilization and supplementary understory light without root exclusion tube in 2007. B. Of experimental fertilization without or without root exclusion tube in 2007. Results are shown as mean and 95\% CI.

\begin{tabular}{l|l|lll}
\multicolumn{2}{l|}{ A. } & \multicolumn{3}{|l}{ Seedling mortality } \\
\hline Source & $\begin{array}{l}\text { Root exclusion } \\
\text { tube }\end{array}$ & Effect & $2.5 \%$ & $97.5 \%$ \\
\hline Control & No tube & -0.9 & & \\
Fertilization & No tube & 2.8 & 1.3 & 3.5 \\
Light & No tube & -1.1 & -2.6 & 0.1 \\
Fertilization*Light & No tube & 0.5 & -0.5 & 1.3 \\
\hline
\end{tabular}

The effects are reported as the value for the control and the differences (in italics) between control and the other treatments.

\begin{tabular}{l|l|lll}
\multicolumn{2}{l|}{ B. } & \multicolumn{3}{|l}{ Seedling mortality } \\
\hline Source & $\begin{array}{l}\text { Root exclusion } \\
\text { tube }\end{array}$ & Effect & $2.5 \%$ & $97.5 \%$ \\
\hline Fertlization & Tube & 2.2 & & \\
Fertlization & No tube & -0.3 & -1.7 & 1.2 \\
\hline
\end{tabular}

The effects are reported as the mean of seedling mortality with root exclusion tube and the difference (in italic) between the mean of seedling mortality with root exclusion tube and the mean of seedling mortality without root exclusion tube. 
Table S4. Transplanted seedling mortality: model comparison for the two alternative hypotheses. Table shows the output from the GLMM statistical analysis giving likelihood ratio tests, information criteria values (AIC), model probabilities ( $\omega$ i) and evidence ratios $(E)$ comparing the models using the AIC (AICc produces qualitatively identical results). There was no main effect of the root exclusion tube (below) or interaction with the fertilization treatment and hence no support for a role of belowground competition in diversity loss following fertilization.

\begin{tabular}{l|llllllll} 
Model & Df & AIC & logLik & Chisq & Chi Df & P & wi & $E$ \\
\hline Intercept & 5 & 293 & -142 & & & & 0.000 & 327747.9 \\
Fert & 6 & 286 & -137 & 9.5 & 1 & 0.0021 & 0.000 & 7903.0 \\
Fert + Light & 7 & 268 & -127 & 20.0 & 1 & $<0.0001$ & 1.000 & 1.0 \\
Fert + Light + Tube & 8 & 269 & -126 & 1.3 & 1 & 0.25 & 0.418 & 1.4
\end{tabular}

Table S5. Effect (pH measured in 2007) of experimental fertilization and supplementary understory light. Results are shown as mean and 95\% CI.

\begin{tabular}{l|lll}
2006 & $\mathrm{pH}$ & & \\
\hline Source & Effect & $2.5 \%$ & $97.5 \%$ \\
\hline Control & 7.23 & & \\
Fertilization & -0.07 & -0.15 & 0.02 \\
Light & 0.02 & -0.07 & 0.11 \\
Fertilization + & -0.04 & -0.13 & 0.05 \\
Light & & &
\end{tabular}

The effects are reported as the value for the control and the differences (in italics) between control and the other treatments. 
Table S6. Species occurring for each treatment of the four different species mixtures (pool 1 - 4). In bold, species that were originally in the pre-established 6-species mixture pool. In parenthesis, the species that were lost or gained between 2006 and 2007 are represented by + and - respectively for each replicate. The species that were present in both years are represented by 0 (no change) and the species that were absent in both years from one of the replicates are represented by $\mathrm{x}$. Nomenclature follows Flora Helvetica (S9).

\begin{tabular}{|c|c|c|c|c|}
\hline \multirow[b]{2}{*}{ Treatment } & \multicolumn{4}{|c|}{ Species name } \\
\hline & Pool 1 & Pool 2 & Pool 3 & Pool 4 \\
\hline Control & $\begin{array}{l}\text { Arrhenatherum elatius }(\mathbf{0 , 0}, \mathbf{0}) \\
\text { Crepis biennis }(+, \mathrm{x}) \\
\text { Festuca pratensis }(0,-) \\
\text { Festuca rubra }(-, 0) \\
\text { Gallium mollugo }(\mathbf{0 , 0}) \\
\text { Geranium pratense }(\mathrm{x}, 0) \\
\text { Lolium perenne }(-,-) \\
\text { Medicago lupulina }(-, \mathrm{x}) \\
\text { Plantago major }(\mathrm{x},+) \\
\text { Poa pratensis }(+,-) \\
\text { Poa Trivialis }(\mathrm{x},+) \\
\text { Polygonum aviculare }(\mathrm{x},-) \\
\text { Rumex acetosa }(+, \mathrm{x}) \\
\text { Taraxacum officinale }(-,-) \\
\text { Trisetum flavescens }(+,+) \\
\text { Trifolium pratense }(\mathbf{0 , 0},\end{array}$ & $\begin{array}{l}\text { Alopecurus pratensis }(+, \mathrm{x}) \\
\text { Anagallis arvensis }(+, \mathrm{x}) \\
\text { Centaurea jacea }(\mathbf{0 , 0}) \\
\text { Dactylis glomerata }(+, \mathrm{x}) \\
\text { Festuca rubra }(+, \mathrm{x}) \\
\text { Knautia arvensis }(\mathbf{0},-) \\
\text { Lolium perenne }(\mathrm{x},+) \\
\text { Lychnis flos-cuculi }(+, \mathrm{x}) \\
\text { Medicago lupulina }(\mathbf{0 , 0}) \\
\text { Myosotis arvensis }(0,-) \\
\text { Phleum pratense }(\mathbf{x},-) \\
\text { Plantago lanceolata }(-, 0) \\
\text { Poa pratensis }(\mathbf{0}, \mathbf{0}) \\
\text { Poa Trivialia }(\mathrm{x},+) \\
\text { Silene nutans }(\mathrm{x},+) \\
\text { Taraxacum officinale }(0,0) \\
\text { Trisetum flavescens }(+, 0) \\
\text { Trifolium pratense }(\mathrm{x},+) \\
\text { Veronica persica }(\mathrm{x}, 0) \\
\end{array}$ & $\begin{array}{l}\text { Achillea millefolium }(-, \mathrm{x}) \\
\text { Anagallis arvensis }(\mathrm{x},-) \\
\text { Arrhenatherum elatius }(\mathrm{x},+) \\
\text { Cerastium fontanum }(\mathrm{x},+) \\
\text { Conyza canadensis }(\mathrm{x},-) \\
\text { Festuca pratensis }(\mathrm{x},-) \\
\text { Holcus lanatus }(\mathbf{0 , x}) \\
\text { Lactuca serriola }(\mathrm{x},-) \\
\text { Lamium purpureum }(\mathrm{x},+) \\
\text { Lolium perenne }(0,+) \\
\text { Lychnis flos-cucul }(\mathbf{0 0 , 0}) \\
\text { Medicago lupulina }(+, \mathrm{x}) \\
\text { Poa pratensis }(-, \mathrm{x}) \\
\text { Taraxacum officinale }(\mathrm{x}, 0) \\
\text { Trisetum flavescens }(\mathbf{0 , 0}) \\
\text { Trifolium pratense }(\mathrm{x}, 0) \\
\text { Trifolium repens }(-,-) \\
\text { Veronica persica }(-,, 0)\end{array}$ & $\begin{array}{l}\text { Achillea millefolium }(-,-) \\
\text { Crepis biennis }(-,-) \\
\text { Dactylis glomerata }(0,0) \\
\text { Festuca pratensis }(0,-) \\
\text { Gallium mollugo }(-, \mathrm{x}) \\
\text { Geranium pratense }(\mathbf{0 , 0}) \\
\text { Lactuca serriola }(\mathrm{x},-) \\
\text { Lathyrus pratensis }(\mathrm{x},-) \\
\text { Lolium perenne }(\mathrm{x},+) \\
\text { Medicago lupulina }(-, \mathrm{x}) \\
\text { Phleum pratense }(\mathrm{x},-) \\
\text { Poa pratensis }(+,-) \\
\text { Poa Trivialis }\left(\left(^{-,-)}\right.\right. \\
\text {Setaria viridis }(\mathrm{x},+) \\
\text { Taraxacum officinale }(0,+) \\
\text { Trifolium repens }(+, \mathrm{x}) \\
\text { Veronica persica }(\mathrm{x}, 0) \\
\text { Vicia cracca }(\mathbf{0}, \mathbf{0})\end{array}$ \\
\hline Fertilization & $\begin{array}{l}\text { Achillea millefolium }(-, \mathrm{x}) \\
\text { Arrhenatherum elatius }(\mathbf{0 , 0}) \\
\text { Festuca pratensis }(\mathrm{x},-) \\
\text { Festuca rubra }(+, \mathbf{0}) \\
\text { Gallium mollugo ( }(\mathbf{0 , 0}) \\
\text { Geranium pratense }(\mathrm{x}, 0) \\
\text { Lolium perenne }(\mathrm{x},-) \\
\text { Medicago lupulina }(\mathrm{x},-) \\
\text { Poa pratensis }(-,-) \\
\text { Poa Trivialis }(+, \mathrm{x}) \\
\text { Sonchus asper }(\mathrm{x},-) \\
\text { Taraxacum officinale }(-,-) \\
\text { Trisetum flavescens }(0,+) \\
\text { Trifolium pratense }(0,0) \\
\text { Veronica persica }(-,-)\end{array}$ & $\begin{array}{l}\text { Centaurea jacea }(\mathbf{0},-) \\
\text { Cerastium fontanum }(-, \mathrm{x}) \\
\text { Dactylis glomerata }(-, \mathrm{x}) \\
\text { Festuca pratensis }(-, \mathrm{x}) \\
\text { Gallium mollugo }(\mathrm{x},-) \\
\text { Knautia arvensis }(-,-) \\
\text { Lolium perenne }(\mathrm{x},+) \\
\text { Lychnis flos-cuculi }(-,-,) \\
\text { Medicago lupulina }(\mathbf{0 , 0}) \\
\text { Myosotis arvensis }(0,-) \\
\text { Plantago lanceolata }(\mathbf{x},-) \\
\text { Poa pratensis }(\mathbf{0}, 0) \\
\text { Poa Trivialis }(+,+) \\
\text { Sonchus asper }(\mathrm{x},+) \\
\text { Taraxacum officinale }(0,0) \\
\text { Trifolium pratense }(\mathrm{x},+) \\
\text { Veronica persica }(\mathrm{x}, 0)\end{array}$ & $\begin{array}{l}\text { Alopecurus pratensis }(\mathrm{x},+) \\
\text { Anagallis arvensis }(+, \mathrm{x}) \\
\text { Cerastium fontanum }(\mathrm{x},-) \\
\text { Festuca pratensis }(\mathrm{x},-) \\
\text { Holcus lanatus }(-,, 0) \\
\text { Lamium purpureum }(+, \mathrm{x}) \\
\text { Lepidium campestre }(+, \mathrm{x}) \\
\text { Lolium perenne }(+, 0) \\
\text { Lychnis flos-cuculi }(\mathbf{0}, 0) \\
\text { Papaver rhoeas }(-, \mathrm{x}) \\
\text { Phleum pratense }(\mathrm{x},-) \\
\text { Poa pratensis }(\mathrm{x},-) \\
\text { Rumex acetosa }(0, \mathrm{x}) \\
\text { Silene nutans }(+, \mathbf{x}) \\
\text { Taraxacum officinale }(-,-) \\
\text { Trisetum flavescens }(-, 0) \\
\text { Trifolium pratense }(\mathrm{x}, 0) \\
\text { Trifolium repens }(-, \mathrm{x}) \\
\text { Veronica persica }(-, \mathrm{x}) \\
\end{array}$ & $\begin{array}{l}\text { Achillea millefolium }(-,-) \\
\text { Arrhenatherum elatius }(-,-) \\
\text { Crepis biennis }(-,-) \\
\text { Dactylis glomerata }(0,0) \\
\text { Festuca pratensis }(\mathbf{0},-) \\
\text { Geranium pratense }(\mathbf{0}, 0) \\
\text { Lactuca serriola }(\mathrm{x},-) \\
\text { Lolium perenne }(\mathrm{x},+) \\
\text { Poa pratensis }(-,+) \\
\text { Poa Trivialis }(+,-) \\
\text { Taraxacum officinale }(0,-) \\
\text { Veronica persica }(\mathrm{x},-) \\
\text { Vicia cracca }(\mathbf{0}, \mathbf{0})\end{array}$ \\
\hline Light & $\begin{array}{l}\text { Arrhenatherum elatius }(\mathbf{0 , 0}) \\
\text { Festuca pratensis }(0, \mathrm{x}) \\
\text { Festuca rubra }(0,+) \\
\text { Gallium mollugo }(0,0) \\
\text { Geranium pratense }(\mathrm{x}, 0) \\
\text { Knautia arvensis }(+, \mathrm{x}) \\
\text { Lolium perenne }(-, \mathrm{x}) \\
\text { Medicago lupulina }(0, \mathrm{x}) \\
\text { Plantago lanceolata }(\mathrm{x},+) \\
\text { Poa pratensis }(+, \mathrm{x}) \\
\text { Poa Trivialis }(\mathrm{x},+) \\
\text { Rumex acetosa }(\mathrm{x},+) \\
\text { Silene nutans }(+, \mathrm{x}) \\
\text { Taraxacum officinale }(-,, 0) \\
\text { Trisetum flavescens }(+,+) \\
\text { Trifolium pratense }(\mathbf{0}, \mathbf{0}) \\
\text { Veronica persica }(0,-)\end{array}$ & $\begin{array}{l}\text { Centaurea jacea }(\mathbf{0 , 0}, \\
\text { Conyza canadensis }(-, \mathrm{x}) \\
\text { Dactylis glomerata }(\mathrm{x},-) \\
\text { Festuca pratensis }(\mathrm{x},+) \\
\text { Gallium mollugo }(-,+) \\
\text { Knautia arvensis }(\mathbf{0},-) \\
\text { Lolium perenne }(\mathrm{x},+) \\
\text { Lychnis flos-cuculi }(+,+) \\
\text { Medicago lupulina }(\mathbf{0 , 0}) \\
\text { Myosotis arvensis }(0, \mathrm{x}) \\
\text { Phleum pratense }(-, \mathrm{x}) \\
\text { Plantago lanceolata }(+,+) \\
\text { Plantago major }(+, \mathrm{x}) \\
\text { Poa pratensis }(\mathbf{0}, \mathbf{0}) \\
\text { Poa Trivialis }(+,+) \\
\text { Setaria viridis }(\mathrm{x},+) \\
\text { Taraxacum officinale }(0,0) \\
\text { Trisetum flavescens }(\mathrm{x}, 0) \\
\text { Trifolium pratense }(\mathrm{x}, 0) \\
\text { Veronica persica }(-, 0)\end{array}$ & 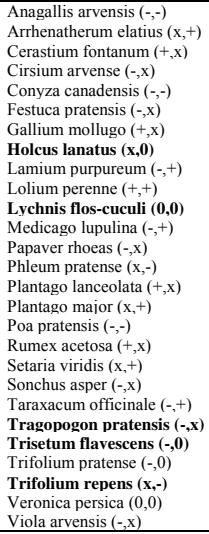 & $\begin{array}{l}\text { Achillea millefolium }((-,) \\
\text { Anagallis arvensis }(\mathrm{x},+) \\
\text { Cerastium fontanum }(-, \mathrm{x}) \\
\text { Crepis biennis }(-,-) \\
\text { Dactylis glomerata }(\mathbf{0}, \mathbf{0}) \\
\text { Festuca pratensis }(\mathbf{0},-) \\
\text { Geranium pratense }(\mathbf{0 , 0}) \\
\text { Lactuca serriola }(\mathrm{x},-) \\
\text { Lamium purpureum }(\mathrm{x},-) \\
\text { Lolium perenne }(\mathrm{x},+) \\
\text { Medicago lupulina }(0,-) \\
\text { Poa pratensis }(-,+) \\
\text { Poa Trivialis }(+,-) \\
\text { Silene nutans }(\mathrm{x},+) \\
\text { Taraxacum officinale }(0,0) \\
\text { Veronica persica }(\mathrm{x}, 0) \\
\text { Vicia cracca }(\mathbf{0 , 0})\end{array}$ \\
\hline $\begin{array}{c}\text { Fertilization } \\
+ \text { Light }\end{array}$ & $\begin{array}{l}\text { Achillea millefolium }(+, \mathrm{x}) \\
\text { Arrhenatherum elatius }(\mathbf{0 , 0}) \\
\text { Festuca pratensis }(\mathrm{x},-) \\
\text { Festuca rubra }(-,-) \\
\text { Gallium mollugo }(\mathbf{0}, \mathbf{0}) \\
\text { Geranium pratense }(\mathrm{x}, 0) \\
\text { Leucanthemum vulgare }(-, \mathbf{x}) \\
\text { Lolium perenne }(0,-) \\
\text { Medicago lupulina }(-, \mathrm{x}) \\
\text { Poa pratensis }(0, \mathrm{x}) \\
\text { Poa Trivialis }(\mathrm{x},+) \\
\text { Taraxacum officinale }(-,, 0) \\
\text { Trisetum flavescens }(+,+) \\
\text { Trifolium pratense }(\mathbf{0}, \mathbf{0}) \\
\text { Veronica persica }(-, 0)\end{array}$ & $\begin{array}{l}\text { Centaurea jacea }(\mathbf{0 , 0}) \\
\text { Conyza canadensis }(\mathrm{x},+) \\
\text { Dactylis glomerata }(0, \mathrm{x}) \\
\text { Festuca pratensis }(\mathrm{x}, 0) \\
\text { Festuca rubra }(\mathrm{x},+) \\
\text { Holcus lanatus }(\mathrm{x},+) \\
\text { Knautia arvensis }(-,-) \\
\text { Lolium perenne }(\mathrm{x}, 0) \\
\text { Lychnis flos-cuculi }(+,-) \\
\text { Medicago lupulina }(\mathbf{0 , 0}) \\
\text { Myosotis arvensis }(0, \mathrm{x}) \\
\text { Phleum pratense }(-,-) \\
\text { Plantago lanceolata }(\mathbf{0},+) \\
\text { Poa pratensis }(\mathbf{0}, \mathbf{0}) \\
\text { Poa Trivialis }(\mathrm{x},+) \\
\text { Silene nutans }(+, \mathrm{x}) \\
\text { Taraxacum officinale }(0,0) \\
\text { Trisetum flavescens }(0, \mathrm{x}) \\
\text { Veronica persica }(-,-)\end{array}$ & $\begin{array}{l}\text { Alopecurus pratensis }(+,+,) \\
\text { Anagallis arvensis }(-,-) \\
\text { Arrhenatherum elatius }(+, 0) \\
\text { Conyza canadensis }(-, \mathrm{x}) \\
\text { Festuca pratensis }(0,+) \\
\text { Holcus lanatus }(\mathbf{0 , 0}, \mathbf{0} \\
\text { Lamium purpureum }(0, \mathrm{x}) \\
\text { Lolium perenne }(0,0) \\
\text { Lychnis flos-cuculi }(\mathbf{0 , 0}) \\
\text { Phleum pratense }(\mathrm{x},-) \\
\text { Plantago lanceolata }(+, \mathrm{x}) \\
\text { Poa pratensis }(-,-) \\
\text { Polygonum aviculare }(\mathrm{x},-) \\
\text { Rumex acetosella }(-, \mathrm{x}) \\
\text { Setaria viridis }(\mathrm{x},+) \\
\text { Silene nutans }(\mathbf{x},+) \\
\text { Taraxacum officinale }(-,+) \\
\text { Trisetum flavescens }(\mathbf{0}, \mathbf{0}) \\
\text { Trifolium pratense }(\mathrm{x}, 0) \\
\text { Veronica persica }(0,0) \\
\end{array}$ & $\begin{array}{l}\text { Achillea millefolium }(\mathbf{0},-) \\
\text { Crepis biennis }((-,-) \\
\text { Dactylis glomerata }(\mathbf{0}, \mathbf{0}) \\
\text { Festuca pratensis }(-,-) \\
\text { Gallium molluga }(+,,) \\
\text { Geranium pratense }(\mathbf{0 , 0}) \\
\text { Knautia arvensis }(+, \mathrm{x}) \\
\text { Lolium perenne }(0,0) \\
\text { Medicago lupulina }(0, \mathrm{x}) \\
\text { Poa pratensis }(0,-) \\
\text { Poa Trivialis }(+,+) \\
\text { Setaria viridis }(+, \mathrm{x}) \\
\text { Taraxacum officinale }(0,0) \\
\text { Veronica persica }(\mathrm{x}, 0) \\
\text { Vicia cracca }(\mathbf{0}, \mathbf{0})\end{array}$ \\
\hline
\end{tabular}


Table S7. Linear model results of the response of temperature to the distance from the lamp (cm) and the two levels of understory light treatment in the experimental glasshouse at University of Zurich in 2007. The intercept is the temperature of the lamp in the closed light treatment. Enclosed lights increased temperature by the same amount as open lights. Results are shown as mean and 95\% CI.

\begin{tabular}{l|lll} 
& \multicolumn{3}{|l}{ Temperature } \\
\hline Source & Effect & $2.5 \%$ & $97.5 \%$ \\
\hline Intercept & 23.7 & & \\
Distance & -0.1 & -0.2 & -0.1 \\
Light & 0.1 & -0.3 & 0.4 \\
Distance*Light & 0.1 & -0.1 & 0.1
\end{tabular}

\section{References}

S1. L. Wacker, O. Baudois, S. Eichenberger-Glinz, B. Schmid, Basic and Applied Ecology 9, 467 (2007).

S2. H. J. Smit, M. J. Metzger, F. Ewert, Agric. Syst. 98, 208 (2008).

S3. B. Steingrobe, H. Schmid, N. Claassen, J. Plant Nutr. Soil Sci.-Z. Pflanzenernahr. Bodenkd. 163, 617 (2000).

S4. A. Gelman, J. Hill, Data Analysis Using Regression and Multilevel/Hierarchical Models (Cambridge Univ. Press, Cambridge, ed. 2, 2007).

S5. D. Bates, R News 5, 27 (2005).

S6. J. J. Faraway, Extending the Linear Model with R: Generalized Linear, Mixed Effects and Nonparametric Regression Models (Chapman \& Hall/CRC, 2005).

S7. D. Maindonald, J. Braun, Data Analysis and Graphics Using R (Cambridge University Press, ed. 2, 2007).

S8. R Development Core Team, A Language and Environment for Statistical Computing (R Foundation for Statistical Computing, Vienna, Austria, 2008).

S9. K. Lauber, G. Wagner, Flora Helvetica; Flore Illustrée de Suisse (Haupt, ed. 2, 2001). 